\title{
The conundrum of conservation agriculture and livelihoods in Southern Africa
}

\author{
Peter Nkala ${ }^{1 \star}$, Nelson Mango ${ }^{2}$, Marc Corbeels ${ }^{3}$, Gert Jan Veldwisch ${ }^{4}$ and Jeoroen Huising ${ }^{5}$ \\ ${ }^{1}$ Centre for Development Research (CDR), BOKU, University of Natural Resources and Applied Life Sciences, Vienna, \\ Gregor Mendel Strasse 33, A-1180 Vienna, Austria. \\ ${ }^{2}$ Centre for International Tropical Agriculture (CIAT), $12.5 \mathrm{~km}$ peg, Mazoe Road, Harare, Zimbabwe. \\ ${ }^{3}$ UR Annual Cropping Systems Center for International Cooperation in Agronomic Research for Development, (CIRAD), \\ Avenue Agropolis, 34398 Montpellier Cedex 5, France. \\ ${ }^{4}$ Irrigation and Water Engineering Group, Wageningen University, Droevendaalsesteeg 3a, 6708 PB Wageningen, \\ Netherlands. \\ ${ }^{5}$ Soil Scientist and Coordinator of the Below-Ground Bio-Diversity (BGBD) Project, TSBF-CIAT, ICRAF Campus, UN \\ Avenue, Gigiri, P. O. Box 30677-00100, Nairobi, Kenya.
}

Accepted 25 August, 2011

\begin{abstract}
Low crop productivity, food insecurity, hunger and malnutrition; inadequate farming knowledge and skills, implements and inputs are characteristic of smallholder agriculture in Southern Africa. Many researchers argue that conservation agriculture can guarantee higher crop productivity, food security, improved livelihoods and environmental protection, better than the unsustainable traditional systems of slash and burn practices. In this paper, we present the results of a meta-analysis of over $\mathbf{4 0}$ academic publications to review conservation agriculture's role in influencing desired livelihood outcomes in Southern Africa. We conclude that the effectiveness of conservation agriculture towards better livelihood outcomes in Southern Africa remains debatable, especially when supportive government policies are lacking.
\end{abstract}

Key words: Adoption, adaptation, conservation agriculture, smallholder farmers, livelihoods, Southern Africa.

\section{INTRODUCTION}

Low crop productivity, food insecurity, hunger and malnutrition characterize poor rural smallholder agriculture based communities in Southern Africa. These communities experience problems of inadequate farming knowledge and skills, and insufficient implements and inputs such as seeds, fertilizers, herbicides and pesticides. In general, soil fertility management is poor and climatic conditions are unpredictable and in most cases very extreme. Consequently these factors force smallholder farmers to engage in resource mining activities to earn a living. Conservation agriculture (CA) and agro-ecology $(\mathrm{AE})$ emerged as response strategies to increase food supply with a sustainable environmental protection (Fowler et al., 2001; Hobbs, 2007; Derpsch, 2005).

*Corresponding author. E-mail: peter.nkala@boku.ac.at. Tel: + 431476542969.
Although the promotion of CA in Southern Africa started many years ago this slowed down with advent of western oriented agronomic technologies and practices (Fowler et al., 2001; Pretty, 2000). Conservation agriculture and other agricultural practices based on indigenous knowledge and practices are of late gaining support of many agronomists and researchers (Kassie et al., 2009).

The Food and Agricultural Organization of the United Nations (FAO), government ministries, non-governmental organization and national and international research institutes have been making conceited efforts to promote CA in Southern Africa since the mid 1980s (FAO, 2001). These efforts hinged on the successful implementation of CA technology in South American countries under similar climatic conditions as those of Southern Africa as well as many others in other parts of the world (Gowing et al., 2008; Giller et al., 2009). The promotion of CA in Southern Africa has largely ignored unique socioeconomic conditions of farmers in the region; a factor 


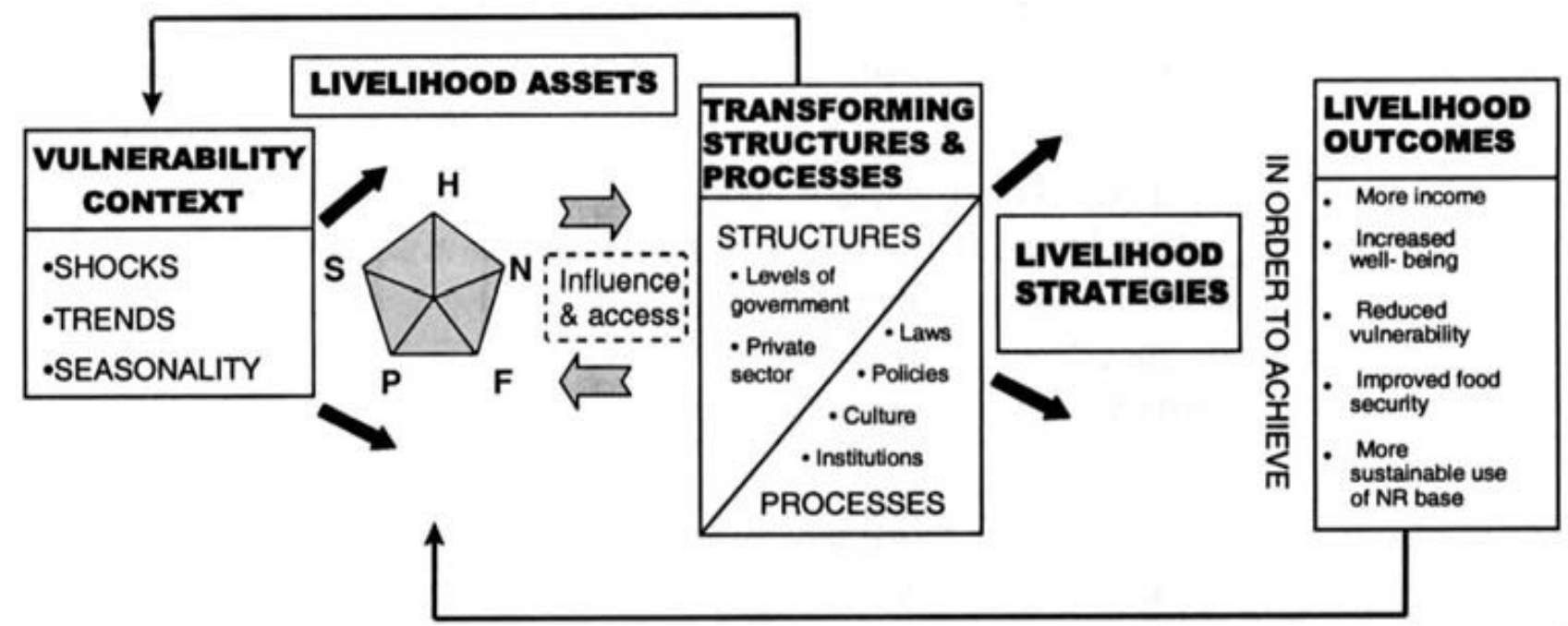

Figure 1. The sustainable livelihoods framework. Source: Adapted from Miranda Cahn (2003), sustainable livelihoods: concept and practice, Massey University.

that requires a different approach to what happened in Brazil and Argentina (Altieri, 1999). Scientists have been cautioned against promoting $\mathrm{CA}$ as a panacea to agricultural challenges associated with poor performance in Sub-Saharan Africa (SSA) and that a critical analysis of CA's potential in the region has been missed (Giller et al., 2009). Mazvimavi et al. (2009) further argue that lack of published studies on adoption of CA leads to wrong conclusions on how farmers in Southern Africa received technologies.

\section{Rationale}

There are various studies that concentrate on adoption, productivity, energy savings and other benefits of CA yet there are only a few that attempt to explore the link between CA and livelihoods. This paper sets out to do the latter. The paper discusses CA and possible challenges in using $\mathrm{CA}$ as a vehicle towards better livelihoods for smallholder farmers in Southern Africa. Livelihood outcomes such as changes in household incomes, vulnerability, food security and welfare of smallholder farmers as outlined in the sustainable livelihoods framework (Cahn, 2003) are discussed in this paper.

\section{METHODS}

The paper is a meta-analytical review of 5 books, 16 journal articles, 7 bulletins, 5 conference papers, 4 unpublished research reports, 2 discussion and 3 working papers, $2 \mathrm{PhD}$ theses and some grey literature. The authors' own experiences with CA from various countries in the region have also been used in this paper. The major focus of reviewed articles is broad concepts of CA and livelihoods in Southern Africa. Table 1 is a summary of various data sources used in the paper.

\section{The framework}

The sustainable livelihoods framework (SLF) in Figure 1 shows the relationship between resource endowments, livelihood assets, transforming structures/processes and livelihood outcomes (Cahn, 2003). For a detailed discussion on the SLF, see Chambers and Conway (1992). In this paper we analyze enabling factors required for positive livelihood transformations through CA given evidence from developing countries as demonstrated in studies by Lautze (1997) and Scoones (1998) in their application of the SLF.

Despite the widespread adoption and discussion of the SLF establishment a clear link between agricultural technology and desired livelihood outcomes particularly in the context of Southern Africa has been missed. Many studies concentrate on critical analysis of either SLF or technology adoption. In the other sections we discuss and propose the missing link between CA and livelihoods of smallholder farmers in Southern Africa, but first we define key concepts of livelihoods, CA and adoption that are core in our discussion.

\section{What are livelihoods?}

According to Chambers and Conway (1992), livelihoods comprise people, their capabilities, means of earning a living, including food, income and assets. Sustainable livelihoods are those that can cope and recover from stresses and shocks, maintain and enhance local and global assets, on which livelihoods depend, imparting bequests and opportunities for future generations (Carney, 2002). Shocks are sudden changes or disturbances in the economy which transform into trends or cycles when the events are prolonged or analyzed over time. Integrating expectations of future generations in today's decision making processes is necessary for the achievement of sustainable livelihoods. Niehof (2004) singles out failure to identify sources of livelihoods as one of the weaknesses of this definition of sustainable livelihoods.

Although agriculture is the core livelihood strategy in Southern Africa, agricultural practices by farmers are unsustainable. Carney (2002) and Toner (2002) argue that CA could be a panacea to sustainable livelihoods for smallholder farmers amid poverty, vulnerability, political and economic instability and civil conflicts.

However, Gowing et al. (2008) and Giller et al. (2009) disagree 
Table 1. Summary of data sources consulted.

\begin{tabular}{lc}
\hline Data Source & Number reviewed \\
\hline Books & 5 \\
Journal articles & 16 \\
Discussion / Working papers & 5 \\
Conference papers & 5 \\
Bulletins & 7 \\
PhD Theses & 2 \\
Other (reports, grey literature) & 4 \\
Total & 44 \\
\hline
\end{tabular}

Source: Authors compilation.

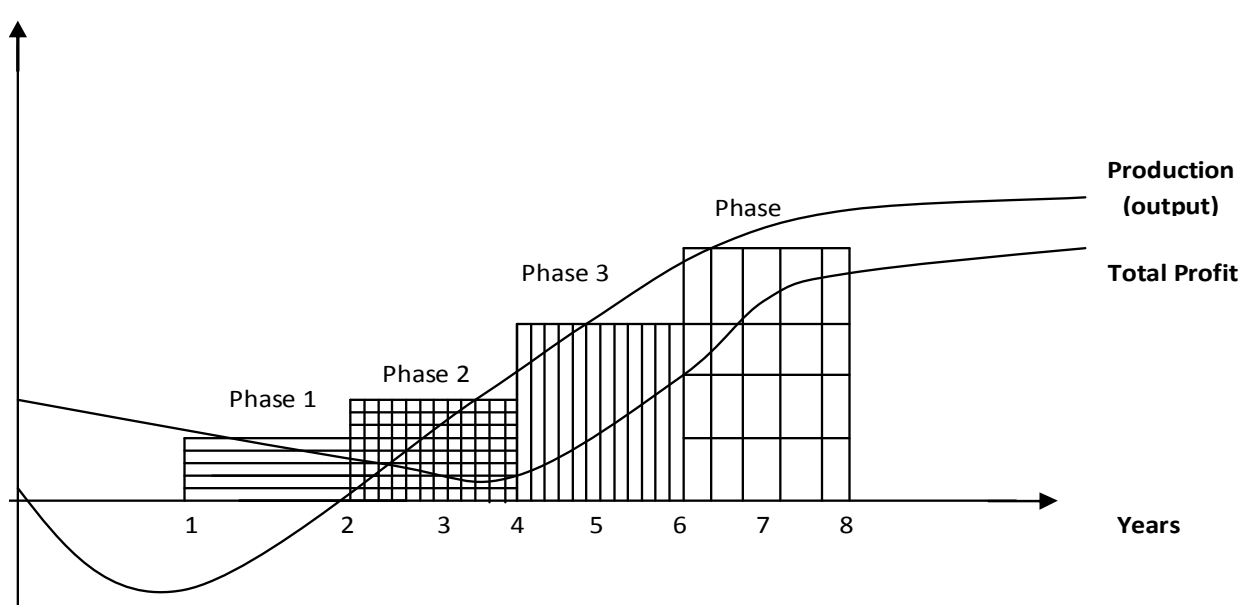

Figure 2. Phases in conversion from traditional to conservation agriculture. Source: Adapted from http://www.fao.org/ag/ca.

and caution against such beliefs.

\section{What is conservation agriculture?}

Conservation agriculture is based on three agronomic principles; (1) minimal soil disturbance, (2) permanent soil cover and (3) crop rotations (FAO, 2001). The first and second principles improve soil fertility, organic matter content and rain water infiltration especially in the 0 to $20 \mathrm{~cm}$ top layer considered the active yet most vulnerable zone for crop production while crop rotation reduces the necessity of pesticides and herbicides in the long run (Derpsch, 2005). According to Hobbs (2006), Hobbs et al. (2006) and FAO (2001) conservation agriculture is a technology that conserves, improves and efficiently utilizes resources through integrated management of available resources combined with external inputs. The technology is variously known as conservation tillage, notillage, and zero-tillage; direct seeding/planting and crop residue mulching (Baker et al., 1996; Ereinstein, 1999; Fowler et al., 2001).

Another variation of CA that has been promoted by the International Crop Research Institute for the Semi Arid Tropics (ICRISAT), the Food and Agricultural organization of the United Nations (FAO) and some local non-governmental organizations (NGOs) in Zimbabwe and Malawi is known as precision conservation agriculture (PCA) (Twomlow et al., 2008). PCA rests on four principles of; (a) minimum tillage; (b) precise application of small doses of nitrogen fertilizer; (c) combining high soil fertility with improved seed and (d) use of crop residues for permanent soil cover (Twomlow et al., 2008). Although conservation agriculture can be referred to by various names depending on scientists, where $\mathrm{CA}$ is promoted and the type of farmers targeted by the technology; CA hardly exists as a package proposed by the FAO, especially not in Southern Africa.

\section{What constitutes adoption of CA?}

Technology adoption by farmers means sustained technology intervention practices long after projects have been terminated. However what constitutes adoption of CA in Southern Africa is not clear as different meanings have been espoused by different authors resulting in questions on whether to consider adoption as a 'discrete state with binary variables or a continuous measure?' (Giller et al., 2009; Doss, 2006). Pannell et al. (2006) argue that adoption is not an all-or-nothing decision characterized by a grey area between small-scale trialing and eventual adoption. For example, Doss (2006) states that a farmer growing at least one improved variety was considered an adopter in the 22 projects in East Africa that were implemented by the International Maize and Wheat Improvement Center (CIMMYT).

The phases in the conversion from traditional to conservation agriculture are as shown in Kaumbutho et al. (2007). Figure 2 shows adoption as a continuous but non linear process occurring in phases of varying time frames, steps and sometimes ending in 
partial rather than full adoption.

There are various phases of the behavior of output and profits during the adoption of CA, where the two decline initially before becoming positive. Phase 1 is mainly a learning phase during which farmers learn about the techniques of zero tillage as they adjust from traditional agricultural systems to CA. This first phase is characterised by decreases in labour, time and animal traction and accompanied by increases in the demand for agrochemicals (FAO, 2004). Improvements in soil fertility and further increases in crop yields are experienced during phase 2. Minimal profits realised at this stage are used to purchase appropriate implements and inputs. The cropping pattern gets more diversified leading to stable yields and further soil fertility improvement in phase 3 . Total yield stability is achieved with peaks in both productivity and profits leading to higher food security, income and enhanced livelihoods in phase 4.

According to FAO $(2001,2004)$ four requirements must be satisfied for the adoption of CA by farmers; (1) benefits must be immediate and visible, (2) benefits must be substantial, (3) costs of technology dissemination must be affordable and finally, (4) support with extension services for considerable periods of time is necessary. Full benefits of CA on livelihoods can only be realized when all the three principles are well established (FAO, 2001).

\section{Promoters of conservation agriculture in Southern Africa}

The Consultative Group on International Agricultural Research (CGIAR) through affiliate organizations such as the Center for International Tropical Agriculture (CIAT), International Maize and Wheat Improvement Center (CIMMYT) and the International Crop Research Institute for the Semi-Arid Tropics (ICRISAT) have shown keen interest on CA in Southern Africa. In addition, FAO working together with ministries of agriculture's extension services and national agricultural research institutions (NARIs) are actively involved in CA projects in the region. Local NGOs like the African Conservation Tillage Network (ACT), Intermediate Technology Development Group (ITDG) and the Organization for Rural Agricultural Progress (ORAP) are major players in CA technology promotion in the region. As a result $C A$ has been introduced in Lesotho, Namibia, Malawi, Mozambique, South Africa, Swaziland, Tanzania, Zambia and Zimbabwe (FAO, 2007). Empirical evidence on CA and livelihoods promotion efforts in Angola, Botswana, and Namibia by various organizations is scarce probably because ranching, mining and other livelihood strategies take precedence over crop farming in some of these countries. Usually funding for CA projects is provided by international research organizations and channeled through local NGOs, government departments and national agricultural research institutions.

In Malawi, Tanzania, Zambia and Zimbabwe CIMMYT facilitates adoption of CA in maize based systems while CIAT attempts to develop sustainable marketing systems that help improve the competitiveness of smallholder farmers. Heltberg et al. (2002) argue that integrating farmers into the market economy requires stimulation of economic growth and development as most poor farmers remain outside the cash economy due high transaction costs and associated risks.

\section{ADOPTION AND ADAPTATION OF CA IN SOUTHERN AFRICA}

Conservation agriculture in Southern Africa is characterized by partial adoption, sometimes referred to as 'distorted adoption' or 'farmer uptake' (Giller et al., 2009). From the dichotomous understanding of the $C A$ concept, we note that there is marginal or zero-adoption but adaptation to ensure CA complies with local conditions. Farmers are risk averse, and careful about experimenting with unknown technologies hence traditional practices usually continue on other parts of the fields.

Observations in Mozambique show that smallholder farmers could adopt CA on any of their fields except where they would have planted sorghum because the 'stubbornness' of sorghum residues forces farmers to burn them as they prepare the land for the next planting season. In Zambia, Haggblade et al. (2003) lament lack of resources limiting smallholder farmers' in practicing ideal CA on all their land. The technology is implemented on small plots as an insurance against drought and famine since many believed that CA guarantees some level of yields even during years of drought. About 125 farmers, interviewed in central and southern Zambia revealed that $25 \%$ of cotton and $50 \%$ of their maize plots were under CA and overall CA accounted for 10 to $20 \%$ of cultivated land.

Alongside (partial) adoption also dis-adoption of CA occurs, hence it is not surprising that there are many claims of adoption of CA during tenure of NGO and NARI programs which disappear when the projects terminate, raising critical questions about the sustainability of $\mathrm{CA}$ (Giller et al., 2009; Bolliger, 2007). When forerunners of CA like World Vision International (WVI), Development Aid from People to People (DAPP), the Southern Province Household Food Security Programme (SPHFSP) and the Monze Dioceses in Zambia terminated projects in 2003, no evidence of CA remained on the ground.

There are many explanations for these CA adoption practices in Southern Africa. Some farmers join CA projects to access cheap inputs and other forms of support but revert to their traditional farming practices when such assistance stops. Inability to cope with intensive technology management requirements of $\mathrm{CA}$ as evidenced in Zambia also lead to dis-adoption of CA (Haggblade et al., 2003; Mashingaidze et al., 2006). Furthermore, ordinary smallholder farmers cannot emulate well resourced research institutions and NGOs despite skills and knowledge acquired from extension workers and scientists. In most cases only a few farmers who are not representative of the majority of local farmers participate in CA programmes introduced by NGOs. In addition, CA is not a technology for the poorly resourced farmers typically found in most countries in Southern Africa. The majority of farmers has no access to capital for purchase of agricultural implements and cannot afford ever rising costs for agrochemicals, seeds and other inputs (Lal, 2009). Finally, we note that smallholder farmers in Southern Africa have reservations about the $\mathrm{CA}$ because the reductions in yields in the first few years worsen the already desperate situation of food security.

We acknowledge that modern farmers are active participants, experimenters and re-designers of technologies fitting it into their specific conditions. 
Changing soil fertility, climatic conditions and socioeconomic factors throughout the trialing period coupled with the individual famer's economic, social and environmental goals influence adoption and adaptation patterns of the technology. We note that in some regions of Southern Africa $\mathrm{CA}$ is an attempt to dismantle traditional systems of rotational fallow, slash and burn agriculture still strong in the minds of the farmers. For this reason smallholder farmers never completely discard traditional agricultural systems and practices despite aggressive attempts to introduce new and innovative technologies. Solving adoption problems requires respecting the farmers' experiences and knowledge of their local conditions.

\section{The livelihood impacts of conservation agriculture in Southern Africa}

The commonly discussed positive impacts of CA include increases in productivity through higher crop yields implying food security and consequently better economic and social wellbeing. Pretty $(1998,2000)$ noted these livelihood benefits among farmers who participated in the Machobane farming system in Butha Buthe and Tebellong communities in Lesotho. In Zambia, Haggblade et al. (2003) reported that CA livelihood outcomes among initial CA adopters include productivity level increases of 30 to $70 \%$, diversification of production, increased social capital through farmers groups, less dependency on food aid and drought resilience. Fowler et al. (2001) reported increases of yields of up to $3.5 \mathrm{t} \mathrm{ha}^{-1}$ for most major crops and increased food security in the region. Similar results have been reported about $C A$ in Zimbabwe by Twomlow (2006, 2008), Nyagumbo (1999), Fowler et al. (2001) and Mashingaidze et al. (2006). There is also evidence of limited benefits of CA from our discussions with CA farmers in Gondola, Gorongosa and Manica districts in Mozambique. We however take caution that attributing all livelihood benefits to $\mathrm{CA}$ in the absence of robust quantitative approaches capable of isolating effects of other exogenous factors could be oversimplification of an otherwise very complex process.

Farmers usually express negative outcomes of CA including problems of labour distribution among various activities during the agricultural season, especially with weeds. According to Riches et al. (1997) weeding accounts for $60 \%$ of labor required for maize production and requires proper planning and effective management. Observations and discussions with farmers in Gondola, Gorongosa and Manica districts of Mozambique also revealed that there were weed control problems during the 2008/2009 season because of floods and incessant rains. These problems affected women more than men because in most traditional farming systems in the region, women and children are responsible for weeding. The problem becomes worse among smallholder farmers who lack capital to purchase herbicides and pesticides.

\section{DISCUSSION}

Here, we present our discussion on how CA is interlinked with livelihoods with special focus on the technology's potential in Southern Africa taking cognizance of the various components of the sustainable livelihoods framework as discussed in Chambers and Conway (1992). We explore the link between CA and various livelihood outcomes including, vulnerability, capital assets, livelihood strategies and institutional arrangements on the understanding that economic and agricultural systems depend on natural, social, human, physical and financial capital endowments amid intermittent shocks and (seasonal) trends (Coleman, 1990; Putnam, 1993; Costanza et al., 1997; Pretty, 1998; Pretty et al., 2000).

\section{Conservation agriculture and vulnerability in Southern Africa}

Extreme weather patterns, poor soils and lack of institutional support are some of the factors responsible for vulnerability of smallholder farmers in Southern Africa. Cultivation of marginal lands of declining soil fertility and low productivity levels also worsen vulnerability (Norton, 1995). Barrios et al. (2008) argue that agricultural production in SSA has been affected by climate change in the last half of the 20th century. Jones et al. (2008) further argue that impacts of climate change are likely to reduce crop yields by 20 to $30 \%$ by 2050 in already marginal cropping regions thereby necessitating a shift from dependence on cropping to livestock as a livelihood option for most poor rural households. On this front Mozambique suffers from severe droughts in some seasons although the country receives substantial amounts of rainfall during summer (Barrios et al., 2008). Since 2000 , flooding has worsened farm productivity thereby increasing the vulnerability of smallholder farmers to both extreme rainfall patterns. Floods and wild fires damage various infrastructures such as roads and bridges further compounding transportation problems of agricultural inputs, equipment and personnel to remote areas. Poor extension services provision, poorly organized farmers' organizations, poor means of transport, and insufficient housing for extension workers in the districts also aggravate the vulnerability problem. Furthermore, farmers operate in inefficient product and credit markets characterized by highly distorted prices of both inputs and produce (Kassie et al., 2009). Finally, poverty, political and economic instability exacerbate the problem thereby dampening the impact of CA promotion programmes on livelihoods.

\section{Conservation agriculture and ownership of assets in Southern Africa}

Limited access to assets and coping strategies forces farmers in Southern Africa to practice unsustainable 
livelihoods practices (Cahn, 2003). Conservation agriculture requires well resourced smallholder farmers regarding implements; basic finance and other livelihood assets but most farmers lack such basic resources (Heltberg et al., 2002). Lal (2009) argues that lack of proper seeding equipment like jab planters, disc planters, magoye rippers, zero-drills or cattle for draught power are the principal constraints to adoption of CA in SSA. In most cases organizations carrying out interventions provide such equipment during demo trials as happened in Pumbuto, Nhanguo and Ruaca in Mozambique during the 2008/2009 cropping season. Left alone smallholder farmers would use hand hoes, machetes and slashes which basic implements are owned by most farmers.

Although about $94 \%$ of rural households' livelihoods in Mozambique are engaged in agriculture, land belongs to the state and farmers have no title to the land thus prohibiting use of land as collateral. We observe that land is not so limiting factor in Mozambique and farmers practice fallow systems to manage soil fertility problems giving the traditional practice of slash and burn system a comparative advantage over CA.

\section{$\mathrm{CA}$ and transformation structures and livelihoods in Southern Africa}

Livelihoods are impacted on by transformation structures and processes which comprise both public and private institutions. The importance of these structures and processes characterized by NGOs, local traditional and central government, cannot be ignored in discussing their role in facilitating livelihood outcomes through CA in Southern Africa. These provide employment; agricultural inputs and equipment and also play a major role in influencing the direction of technology transfer. For example introducing $\mathrm{CA}$ in rural communities entails lobbying first at policy level to convince politicians and government officials.

Rural communities in Southern Africa comprise a diversity of cultures, economies and traditional political systems which influence farmers' perceptions with regards to new agricultural technologies and livelihood patterns. Culture and traditions do influence the distribution of resources and technologies dissemination in various ways. In most cases communal people are not aware of the rules and regulations governing the use of resources such as land and pastures.

In most cases the traditional and secular livelihoods transforming institutions are weak, ineffective and lack capital, financial and human resources for the effective management of common property resources. So are the management structures governing the role of farmers and their involvement, place and rights to resources, patterns of land use and tenure, dispute settlement, leadership and legal systems. Capacities associated with socioeconomic well-being, quality of technology and accessibility, research and extension and government and non-governmental institutional support including policy frameworks expected from administering institutions is largely sub-standard. These institutional problems militate against realization of positive impacts and livelihood outcomes in the smallholder agricultural sectors in the region.

\section{Livelihood strategies and conservation agriculture in Southern Africa}

The potential impact of CA on livelihoods is linked to livelihood strategies which mainly comprise agriculture, remittances, microenterprise and trade among others. Livelihood strategies are various activities or adopted household behavior patterns undertaken to earn a living. These are important part of the assets-activities-outcome cycle in livelihoods analysis. The role of agriculture as a key livelihood strategy generating employment at microlevel and significant contributor to national income cannot be doubted (Doss, 2006). Subsistence agriculture supports approximately $90 \%$ of the households in Southern Africa (Heltberg et al., 2002). The high input requirements of $\mathrm{CA}$ preclude most smallholder farmers engaged in agriculture from realizing full benefits of this technology.

Adopting off-farm livelihood strategies through remittances and pensions is a norm in countries like Lesotho, Malawi, South Africa, Swaziland, and Zimbabwe. Young people migrate to cities in search of greener pastures and formal employment largely because of low and unstable incomes from agriculture. Other livelihood strategies such as brewing traditional beer for sale particularly in Malawi, Mozambique and Zimbabwe, to supplement household income are also common. The success of CA could be realized through the reversal of these off-farm livelihood strategies by exploiting their weaknesses and failures to provide formidable exit from agriculture. However, how CA could facilitate this transition to non-agriculture based livelihood strategies remains debatable and requires more investigation. This will be the subject of future research that seeks to identify livelihood transitions of smallholder farmers that can be attributed to CA in three communities in Gondola, Gorongosa and Manica districts of Mozambique.

\section{Constraints against implementation of CA in Southern Africa}

Here, we outline and discuss constraints likely to be encountered during implementation of CA in Southern Africa noting that there is already a deep-rooted belief that all agriculture is conventional. Conservation agriculture has been successful in communities with fertile soils but its performance on poor degraded soils in 
Southern Africa remains unclear. Giller et al. (2009) argue that the plough has become a symbol of agriculture such that many people involved including, farmers, extension agents, researchers, university professors and politicians find it difficult to believe that agriculture can be possible without tillage'. Moreover, There is skepticism linked to the risk averse disposition of the farmers leading to the reluctance in adopting revolutionary technologies attempting to change the paradigm of farmers. It is difficult to realize a paradigm shift especially on long established practices. The success of CA also depends on its ability to transform mindsets of the smallholder farmers and perceptions on how CA can lead to desired livelihood outcomes.

The top-down approach in technology transfer is another constraint leading to questions whether CA addresses the needs of farmers, scientists or policymakers (Giller et al., 2009)? Non-farmer driven interventions and approaches to technology dissemination tend to fail due to lack of ownership by farmers. The demise of externally driven interventions has been well documented and the introduction of $C A$ in Southern Africa could face a similar fate.

Other constraints directly relate to the principles of $C A$, particularly the permanent soil cover with crop residues for moisture retention, increased soil biological activity and better protection of the soil (Hobbs, 2007). Many farmers in Southern Africa collect crop residues and use them as stock feed especially in mixed farming systems where livestock are a major source of household income (ICRISAT, 2006). Crop residues are also removed by livestock that roam freely in the fields after harvesting in countries like Zimbabwe, Mozambique, Botswana and South Africa. So, for crop residues to effectively provide permanent soil cover or mulching farmers are forced to fence their fields. Twomlow (2008) argues that 'in systems where farmers are used to grazing cattle on other people's fields in winter, suddenly stopping it (for purposes of CA) would be socially unacceptable'. Furthermore, in Ruaca and Pumbuto communities in Mozambique, crop residues are decomposed by ants such that by the time the cropping season begins there will be no residues left in the field. Giller et al. (2009) argue that if mulching using crop residues improves infiltration, reduces surface erosion and water run-off and suppresses weeds then the benefits of mulching are diminished as a result of these processes. Social harmony and justice seen as part of the social benefits of CA may be an anathema whose solution requires the involvement of all farmers.

The shortage or late arrival of inputs, inexperienced personnel and inadequate access to government extension services is a common problem in Southern Africa (Pretty, 2000). In some remote communities in many countries in Southern Africa government agricultural extension services are unknown and due to resource limitations NGOs cannot reach out to all farmers. In some instances where extension services are provided, extension workers look at their involvement in the CA projects as extra work for which they should be remunerated separately. Since CA is a knowledge intensive technology, it would be difficult to successfully promote this technology without the help of well-trained and experienced extension workers.

Finally, financial support for the smallholder sector is limited in most countries with most smallholder farmers lacking access to credit for purchasing farm implements and inputs (Ereinstein, 1999). Financial institutions classify smallholder farmers as high risk borrowers with no immovable property to use as collateral, since they do not even have formal ownership of the land. Access to finance is therefore a serious constraint to the implementation of $\mathrm{CA}$ by the targeted group of smallholder farmers in the region.

\section{Factors akin to livelihood improvements through CA in Southern Africa}

While there is general consensus about the theoretical potential social, economic and environmental benefits of $\mathrm{CA}$ as a sustainable agricultural practice, there are fears about sustainability of these outcomes in practice, especially on smallholder farmers (Giller et al., 2009; Kassie et al., 2009). Heltberg et al. (2002) and Kassie et al. (2009) argue that speedy infrastructure development and increased market opportunities as evidenced in the Dominican Republic, Kenya and Ethiopia, can lead to rapid adoption of CA and hence food security and better livelihoods among smallholder farmers. Jane (1994) believes that subsistence farming has considerable potential if adequate outlets and incentives are present; which in the case of Southern Africa are missing. Strengthening of government policies supportive of CA especially the provision of infrastructure like roads, dams and irrigations schemes is necessary. According to Dumanski et al. (2006) CA is best achieved when it is community driven, and farmers and their associations can identify best options for their local conditions. This way the mistake of taking 'one size fits all approach' linked to the success of CA in other parts of the world could be avoided. Smallholder farmers should no longer be regarded as passive adopters of technologies but active participants in the development of technologies that would work towards improvement of their own livelihoods.

Twomlow et al. (2008) concluded CA will work in Southern Africa if sequenced in a manner that reflects the social, economic and biophysical constraints of the smallholder farmers. In other words CA should be adapted to suit limited resources, and low levels of education, vulnerability and chronic poverty. Technocrats working with farmers should particularize technology interventions to the physical and socioeconomic 
fundamentals of communities involved building on what farmers and their associations 'develop and own'. Such a farmer centered participatory technology development (PTD) approach helps the promoters of CA understand the actual priorities and the various pressing constraints of smallholder farmers, while it may also help farmers understand and appreciate the different principles of CA.

Access to credit is an important factor in up-scaling CA in smallholder agriculture in Southern Africa since the absence of financial capital will prolong the transitions to better livelihoods. Deliberate policies that would enable farmers to use land as collateral in financial institutions however need to be developed through initiatives and discussions between government and financial institutions. This is because destructive elements of conventional tillage were subsidized in Africa through deliberate credit schemes and policies targeting special individuals or farmers groups (Fowler et al., 2001). Such support should not be politicized to enhance social justice and reduce moral hazard among farmers of different political inclinations as some party affiliates may view government assisted loans as 'gratis' and carrying no obligations for repayments on the part of farmers.

\section{Conclusions}

From the discussions, we conclude that with numerous non-agricultural activities that have an equally damaging effect on the environment, CA may not be a sufficient condition for increased productivity and environmental conservation. The potential success of CA hinges on desirable but non-existent conditions casting doubt on realization of the envisaged livelihood benefits of $\mathrm{CA}$ given diverse conditions of farmers across the region. Reducing the length of the different phases in the adoption of CA could accelerate the realization of these livelihood outcomes. Agricultural policies that put sustainable agriculture at the centre, with appropriate donor and government support, incentives, and institutional reform, are necessary for the transformation of farmers' livelihoods through CA.

Given the issues discussed, the implementation of CA should acknowledge and address the existing economic and ecological constraints facing farmers. Smallholder farmers should be given an opportunity to adapt CA to their local conditions, experimenting with several components to assess what aspects of CA work for them, where, how and when. Farmers should also be made to realize that switching to CA results in declining yields in the short-run calling for patience and necessary policy support through social safety nets during the transition period. Finally, we note that without required infrastructure, resources and skills for technology transfer, CA's potential contribution to livelihoods in Southern Africa remains a conundrum and subject of further research.

\section{ACKOWLEDGEMENTS}

The authors would like to express their gratitude for funding from BOKU and CIAT and also to the International Centre for Maize and Wheat Improvement Institute for giving us access to their conservation agriculture projects in Mozambique. We are also grateful for comments received on earlier drafts of this paper from various researchers including Jemima Njuki, Precious Zikhali, Ika Darnhofer and members of the Centre for Development Research at BOKU. The views expressed in this paper are entirely those of the authors

\section{REFERENCES}

Altieri MA (1999). Enhancing the productivity of Latin American traditional peasant farming systems through an agro-ecological approach, Paper for Conference on Sustainable Agriculture: New Paradigms and Old Practices?, Italy, Bellagio Conference Center, 2630 April 1999.

Baker CJ, Saxton KE, Ritchie WR (1996). Comparison of some tillage methods on soil physical properties and yield of maize and style in degraded ferruginous tropical soil. Soil Till., 18: 63-72.

Barrios S, Ouattara B, Strobl E (2008). The impact of climatic change on agricultural production, Is it different for Africa? Food Policy 33: 287-298.

Bolliger A (2007). Is Zero-Till an appropriate agricultural alternative for disadvantaged smallholders of South Africa? A study of surrogate systems and strategies, smallholder sensitivities and soil glycoproteins. PhD Thesis. University of Copenhagen.

Cahn M (2003). Sustainable Livelihood Approach: Concepts and Practice, Massey University.

Carney D (2002). Sustainable Livelihoods approaches: Progress and Possibilities for change. Department for International Development. London.

Chambers R, Conway G (1992). Sustainable Rural Livelihoods: Practical Concepts for the 21st Century. IDS. Discussion Paper 296: 7 - 8.

Coleman J (1990). Foundations of Social Theory, Mass., Harvard University Press.

Costanza R, d'Arge R, de Groot R, Farber S, Grasso S, Hannon B, Limburg K, Naeem S, O'Neil RV, Parvelo J, Raskin RG, Sutton P, van den Belt M (1997). The value of the world's ecosystem services and natural capital. Nature, 387: 253-260.

Derpsch $R$ (2005). The extent of Conservation agriculture adoption worldwide - Implications and impacts, in: Third World Congress on Conservation Agriculture: Linking livelihoods and Conservation". Nairobi. October 3-7, 2005.

Doss C (2006). Analyzing Technology Adoption using micro-studies: Limitations, challenges and opportunities for improvement. Agric. Econ., 34: 207-219.

Dumanski J, Peiretti R, Benites JR, McGarry D, Pieri C (2006). The paradigm of Conservation Agriculture. World Association of Soil and Water Conservation. Paper No. pp. 1-70.

Ereinstein OCA (1999). The economics of Soil Conservation in developing countries: The case of crop residue mulching. PhD Thesis. Wageningen University. Netherlands.

Food and Agriculture Organization (FAO) 2001. The economics of soil productivity in Africa. Soils Bulletin. Rome.

Food and Agriculture Organization (FAO) 2004. Conservation of natural resources for sustainable agriculture: training modules. FAO land and water Digital Media Series CD-RM 27. http://www.fao.org/ag/ca/.

Food and Agriculture Organization (FAO) 2007. Workshop on Conservation Agriculture in Southern Africa. Harrison's Conference Centre. Corner $12^{\text {th }}$ Avenue and Wessels Street. Rivonia. Johannesburg. South Africa.

Fowler R, Rockstrom J (2001). Conservation Tillage for Sustainable 
Agriculture, An agrarian revolution gathers momentum in Africa. Soil Till. Res., 61: 93-107.

Giller KEE, Witter E, Corbeels M, Tittonell P (2009). Conservation Agriculture and Smallholder Farming in Africa: The Heretics' view. Field Crops Res., 114(2009): 23-34.

Gowing JW, Palmer M, (2008). Sustainable agricultural development in Sub-Saharan Africa: The case for paradigm shift in land husbandry. Soil Use Manage., 24: 92-99.

Haggblade S, Tembo G (2003). Early evidence on Conservation Farming in Zambia. A paper prepared for the International Workshop on 'Reconciling Rural Poverty and Resource Conservation: Identifying Relationship and Remedies'. Cornell University Ithaca. New York. May 2-3, 2003.

Heltberg R, Tarp F (2002). Agricultural Response and Poverty in Mozambique. Food Policy 27: 103-124.

Hobbs PR (2006). Conservation Agriculture: What is it and why is it important for future sustainable food production. Agric. Econ., 145: 127-137.

Hobbs P, Gupta R, Meisner C (2006). Conservation Agriculture and Its Applications in South Asia. Cornell University.

International Crop Research Institute for the Semi-Arid Tropics (ICRISAT) (2006). Is Conservation agriculture an option for vulnerable households?. Briefing Note by Twomlow, S. and L. Hove. Bulawayo. Zimbabwe.

Jones PG, Thornton PK (2008). Croppers to livestock keepers: livelihood transitions to 2050 in Africa due to climate change, Environmental Science and Policy, article in press.

Kassie M, Zikhali P (2009). The Contribution to Sustainable Agriculture and Land Management to Sustainable Development. Sustainable Development, Innovation Briefs. 7: 05/2009. United Nations.

Kaumbutho P, Kienzle J, eds. (2007). Conservation agriculture as practised in Kenya: two case studies. Nairobi. African Conservation Tillage Network, Centre de Coopération Internationale de Recherche Agronomique pour le Développement, Food Agric. Organ. United Nations.

Lal $R$ (2009). The plough and agricultural sustainability. Sustainable Agric., 33: 66-84.

Lautze S (1997). Saving Lives and Livelihoods: The Fundamentals of a Livelihoods Strategy. Medford. MA. Turfs University.

Mazvimavi K, Twomlow S (2009). Socioeconomic and institutional factors influencing adoption of conservation agriculture by vulnerable households in Zimbabwe. Agric. Syst., 101: 20-29.

Mashingaidze AB, Govere I, Rohrbach D, Hove L, Twomlow S, Mazvimavi K (2006). Review of NGO Efforts to promote Conservation Agriculture in Zimbabwe, 2005/2006 season (unpublished). International Crop Research Institute for the Semi-Arid Tropics (ICRISAT). Zimbabwe.

Norton A (1995). Soil and Water Conservation for Smallholder farmers in Zimbabwe: Past, present and future. In Twomlow S., J. Ellis-Jones, $\mathrm{H}$. Loos. (Editors). Workshop proceedings of Technical Workshop on Soil and Water Conservation for Smallholder farmers in Semi-Arid Zimbabwe. Silsoe Research Institute Report OD/95/16. Masvingo. April 3-7: 5-21.
Niehof A (2004). The significance of diversification for rural livelihood systems. Food Policy, 29: 321-338.

Nyagumbo I (1999). Conservation Tillage for sustainable crop production systems: experiences from on-station and on-farm research in Zimbabwe (1997-1998). In Kaumbutho P.G and T. E. Simalenga. (Editors). Conservation Tillage with Animal Traction. ATNESA. Harare. Zimbabwe.107-114.

Pretty JN (1998). The Living Land: Agriculture, Food Systems and Community Regeneration in Rural Europe. London. Earthscan Publications Ltd.

Pretty J (2000). Can sustainable Agriculture feed Africa? New evidence on progress, processes and impacts. Centre for Environment and Society. University of Essex. Colchester. United Kingdom.

Pretty J, Ward H (2000). Social capital and the environment. World Development.

Putnam RD, Leonardi R, Nanetti RY (1993). Making Democracy Work: Civic Traditions in Modern Italy. Princeton University Press. New Jersey.

Riches CR, Twomlow SJ, Dhliwayo H (1997). Low input weed management and Conservation Tillage in Semi-Arid Zimbabwe. Expt. Agric., 33: 173-187.

Scoones I (1998). Sustainable Rural Livelihoods, A framework for Analysis. IDS Working Paper Number 72. Brighton.

Toner A (2002). Sustainable Livelihoods Approaches - Can they Transform Development? Bradford Centre for International development. Research Paper Number 2. University of Bradford.

Twomlow S J, Hove L, Mupangwa W, Masikati P (2008). Precision conservation agriculture for vulnerable farmers in low-potential zones. International Crop Research Institute for the Semi-Arid Tropics (ICRISAT). Bulawayo. Zimbabwe. 